\title{
Historisk sandhed og narrativ sandhed
}

Den psykoanalytiske fortælling ${ }^{1}$

"Psykoanalytisk litteraturkritik har altid været en noget pinlig affære. Man modsætter sig etiketten 'psykoanalytisk litteraturkritiker', fordi den form for litteraturbeskæftigelse, som betegnelsen fremmaner, for det meste fortjener det dårlige ry, som den selv har skaffet sig«. Med disse ord indleder den amerikanske litteraturkritiker Peter Brooks sin artikel "The Idea of a Psychoanalytic Literary Criticism« fra 1987.2 Citatet - og dets kontekst - er symptomatisk for den mærkbare ambivalens, der kendetegner litteraturforskningens forhold til psykoanalysen: på den ene side utilpasheden ved såkaldt psykoanalytisk litteraturkritik; på den anden side den modvilje mod at opgive psykoanalysen, som Brooks' arbejde er et udtryk for. Vi kritiserer den form for litterær analyse, der med støtte i psykoanalytisk teori og systematik vil blotlægge enten forfatterens, de fiktive personers, tekstens eller læserens ubevidste. Alligevel fortsætter vi, som Brooks bemærker, med at læse »litteraturkritik der er overbroderet med psykoanalysens begrebssprog « (ibid., p.336); drømmen om at forbinde psykoanalyse og litteratur er åbenbart intakt. Men hvad er det, der er i vejen med psykoanalytisk litteraturkritik? Og hvor skal vi vende blikket hen, hvis vi, efter at have forkastet traditionel psykoanalytisk 'indholdsarkæologi', fortsat fastholder troen på en mulig alliance mellem litteraturforskning og psykoanalyse?

Groft generaliserende kan vi sige, at det, der først og fremmest kendetegner psykoanalytisk litteraturkritik, er, at den er så autoritær. Den psykoanalytiske litteraturlæsning mener ikke bare, at den indtager en særstatus i forhold til alle andre mulige læsninger, fordi den har en privilegeret adgang til den litterære teksts allerdybeste betydningslag. Den psykoanalytiske litteraturkritiker havder også, at hans/hendes fortolkning på sæt og vis går forud for den litterære tekst, som den er en analyse af. Shoshana Felman (der nok er den kritiker, som mest indgående har påvist den psykoanalytiske litteraturlæsnings imperialistiske karakter) skriver $i$ artiklen »Turning the Screw of Interpretation«: 
„Set fra den 'freudianske synsvinkel' får seksualiteten, vurderet både som grundlag og retningslinie for den kritiske fortolkning, status af et svar på tekstens spargsmål. Faktisk eksisterer seksualitetens svar både logisk og ontologisk forud for det tekstuelle spørgsmål. Spørgsmålet er kun artikuleret (retorisk, tematisk og fortæilemæssigt), fordi svaret som sådan er skjult. Faktisk er selve spørgsmålet kun et forklædt svar: spørgsmålet er svarets skjulested. I dette perspektiv består den freudianske kritikers job $\mathrm{i}$ at trække svaret frem fra dets skjulested. Det drejer sig ikke så meget om at give et svar til teksten, som at svare for teksten, d.v.s. at være ansvarlig for den, at svare $i$ dens sted, at erstatte spørgsmâlet med et svar «. ${ }^{3}$

Når litterater har tyet til psykoanalysen, har de mere eller mindre direkte givet udtryk for et både forståeligt og legitimt onske, nemlig ønsket om at basere den litterære analyse på noget, der ligger udenfor litteraturen, ønsket om at fă fast grund under fødderne ved at henvise til en disciplin, der antages at være 'videnskabeligt' funderet. Eller som Hayden White formulerer det:

»for at muliggøre forskning indenfor et bvilket som helst humanistisk område, må forskerne forudsætte, at mindst ét andet undersøgelsesområde eller mindst én anden disciplin er effektivt sikret, det vil sige, at det effektivt er unddraget de epistemologiske og metodiske diskusioner, som præger deres eget undersøgelsesområde ${ }^{4}{ }^{4}$

For den psykoanalytiske litteraturkritiker fungerer psykoanalysen som en sådan "effektivt sikret" disciplin. Men paradoksalt nok har den psykoanalytiske litteraturanalyse sin største svaghed der, hvor den tror at have sin styrke. Fra første færd er det blevet hæudet, at psykoanalytiske litteraturkritikere ikke er tilstrækkeligt gode litterater; de »reducerer« det litterære værk. I de senere år har et andet synspunkt vundet indpas - muligvis som en følge af, at litteraterne er begyndt at lese Freud i stedet for bare at læse med ham. For endnu engang at citere fra Felmans artikel: »disse freudianske kritikere har ikke været tilstrækkeligt freudianske« (op.cit. p. 103). De psykoanalytiske litteraturkritikere er ikke nødvendigvis unuancerede litteraturlæsere. Men de er nødvendigvis unuancerede Freud-lasere. 'Nødvendigvis', fordi de netop må tage den psykoanalytiske teori og det psykoanalytiske begrebsapparat for givet. De kommer aldrig længere end til det, som J.Hillis Miller kalder en »kanonisk« læsning af Freud.

Lad mig for et kort øjeblik forlade den psykoanalytiske litteraturkritik og kaste et blik på en tilsyneladende noget anden problemstilling, nemlig den som den amerikanske psykoanalytiker Donald P. Spence behandler i bogen Narrative Truth and Historical Truth. Meaning and Interpretation in Psychoanalysis fra 1982. Emnet for Spences bog er den psykoanalytiske proces, det analytiske/terapeutiske arbejde, sådan som det fremstilles hos Freud. Hensigten er at stille nogle grund- 
læggende spørgsmål til Freuds tekst: Hvad er psykoanalytiske data? Hvilken realitet er det, der fremlyseres i den psykoanalytiske proces? Hvad går psykoanalytisk fortolkning ud på? Hvilken status og hvilken erkendelsesmæssig værdi har den? Spences bog kan læses som en Freud-kritik. Hans basis-antagelse er, at Freud søger at give udtryk af, at den psykoanalytiske proces tilvejebringer et stykke autentisk fortid, en realitet der eksisterer forud for og uafhængigt af selve analysen. Det er denne opfattelse, Spence vil kritisere. Eller mere præcist: han vil argumentere for nødvendigheden af i psykoanalysen at udskifte ét sandhedsbegreb med et andet; istedet for det, der i bogen kaldes »historisk sandhed«, bør vi tale om »narrativ sandhed«. Spences begreb om historisk sandhed kan vi måske bedst bestemme som 'fortiden som den virkelig var'; Freud fremstiller sig selv som en, der udgraver faktiske stykker af fortiden, skriver han. Begrebet »narrativ sandhed «-den sandhedsværdi som den psykoanalytiske fortolkning i følge Spence reelt har - skal jeg senere komme tilbage til. Men jeg kan måske med et citat antyde, hvor Spence vil hen. "Der synes ikke at være tvivl om ", skriver han, "at en velkonstrueret historie besidder en slags narrativ sandhed, som er real og umiddelbar, og som har en vigtig betydning for den proces, der skal føre til terapeutisk forandring ${ }^{5}{ }^{5}$

Spence skelner i sin fremstilling meget skarpt mellem det, Freud gør, og det, Freud siger: Når Freud taler om den psykoanalytiske proces, forveksler han den fortid, der konstitueres gennem fortolkning med fortiden selv; han forveksler »narrativ sandhed « med »historisk sandhed«. Jeg mener imidlertid ikke, at denne skarpe skelnen er formålstjeniig; den diskusion, Spence fører, er, mener jeg, allerede fort af Freud selv, og på en mere perspektivrig måde end hos Spence. Når jeg har draget Spence ind i billedet, er det, fordi begrebsparret historisk og narrativ sandhed (som jeg ganske vist senere skal se mig nødsaget til at revidere) kan bruges som afsætspunkt for en diskussion af den psykoanalytiske proces og af psykoanalytisk læsning og fortolkning i det hele taget. I forlængelse heraf kan vi bruge Spence i forbindelse med spørgsmålet om psykoanalytisk litteraturkritik men på ren negativ vis, så at sige, nemlig i forbindelse med en problematisering af selve grundlaget for denne litteraturkritik. Med udgangspunkt i begrebsparret historisk og narrativ sandhed kan vi sætte spørgsmålstegn ved den psykoanalytiske litteraturkritiks Freud-reception og dermed ved den antagelse, at Freuds tekst uden videre autoriserer den autoritære psykoanalytiske literaturkritik.

For det første: Naturligvis er den psykoanalytiske litteraturlæsning forskellig fra den læsning, som psykoanalytikeren foretager af sin 
patient. Ikke destro mindre henter den psykoanalytiske litteraturlæsning sin begrundelse i det analytiske arbejde, og at stille spørgsmålstegn ved analysens såkaldt »historiske« sandhedsværdi er også at stille spørgsmålstegn ved den psykoanalytiske læsnings autoritet. Vi kan sammenligne forholdet mellem psykoanalytikerens og patientens symptom med forholdet mellem den psykoanalytiske kritiker og det litterære værk: Fælles er at begge står overfor en tekst, som de ikke vil tage for pålydende. Fælles er, at de begge søger at nå ned til den latente sandhed bag den manifeste overflade. Det interessante er imidlertid, at skønt Freud taler om psykoanalysen som en afdækning eller udgravning af en latent, bagvedliggende, realitet, så problematiserer han også selv denne opfattelse, f.eks. i den artikel, som jeg om lidt skal nå frem til. Med udgangspunkt i Freuds egne tekster kan man, som vi skal se, tale om to helt forskellige opfattelser af hvad psykoanalytisk læsning er. På den ene side: psykoanalysen finder/ afdækker en bagvedliggende realitet. På den anden side: den psykoanalytiske læsning konstruerer en realitet, eller, som den franske psykoanalytiker André Green udtrykker det, analysen »konstruerer en mening, der aldrig har været skabt, forend den psykoanalytiske dia$\log$ begyndte ${ }^{6}{ }^{6}$

For det andet er der spørgsmålet om forholdet mellem psykoanalyse og litteratur. Når psykoanalysen inddrages i den litterære fortolkning, er det (som oftest) fordi det litterære værk antages at være et udtryk for forfatterselvet og/eller fordi det antages at iscenesætte de psykiske konflikter, som psykoanalysen har afdækket. Litteraturen og psykoanalysen formodes at tale om det samme objekt, nemlig den menneskelige psyke - men på hver sin måde, for det, som litteraturen kun dunkelt aner, har psykoanalysen formuleret som systematisk teori. Men hvis vi et øjeblik lader være med at betragte psykoanalysen som et sæt svar eller som en dybdepsykologisk viden, så bliver det muligt at få øje på en anden forbindelse mellem psykoanalyse og litteratur - en forbindelse der ikke kræver, at vi ser på litteraturen gennem psykologiske briller. Her vil jeg igen drage Spence ind $\mathrm{i}$ billedet.

Når Spence beskæftiger sig med psykoanalytisk fortolkning og fortolkningsteori, så gør han det i sin egenskab af praktiserende psykoanalytiker. Min interesse er selvsagt af en noget anden art. Men egentlig blev jeg fascineret af Spences bog, netop fordi den er skrevet af en praktiserende psykoanalytiker. Lige siden psykoanalysens barndom har vi set eksempler på, hvorledes psykoanalytikere har brugt psykoanalytisk teori til at sige noget om litteraturen. Her har vi det modsatte tilfælde: en psykoanalytiker, der ser sig nødsaget til at be- 
væge sig ind på litteraturteoriens område og bruge fortællingen og fortælleteorien til at sige noget om psykoanalysen. Spences begreb "narrativ sandhed « antyder, at forholdet mellem psykoanalyse og litteratur er mindre simpelt og entydigt, end de psykoanalytiske kritikere tror. Det antyder, at det ikke bare er litteraturen, der implicerer psykologiske problemstillinger, men at psykoanalysen som sådan implicerer hvad man kunne kalde litterære problemstillinger. Det antyder - for at parafrasere Hayden White - at psykoanalysen alligevel ikke befinder sig effektivt udenfor litteraturforskningens område, d.v.s. alligevel ikke er unddraget de epistemologiske og metodiske diskusioner, der præger litteraturforskningens undersøgelsesområde.

Spences brug af narratologien i diskusionen af den psykoanalytiske proces sætter hans projekt $\mathrm{i}$ forbindelse med f.eks. Roy Schafer og Peter Brooks' arbejder (selvom især sidstnæuntes teoretiske standpunkter på afgørende punkter afviger fra Spences). Fælles er, at de hver for sig har påpeget, at psykoanalysen ikke kan komme uden om fortællingen; den kan ikke komme uden om det narrative. Fortællingen - både forstået som struktur og som fortællehandling - er præsent på alle niveauer af Freuds tekst. Vi kan således med Roy Schafer tale om den psykoanalytiske teori som et sæt af narrative strukturer eller som et sæt af »fortællinger« - fortællinger der ikke er »sekundære beretninger om data", men tværtimod "primære fortællinger som etablerer det, der skal gælde som data «. Eller (hvad der er mere relevant i denne sammenhæng) tale om det, Peter Brooks og Paul Jay kalder "narrativiseringen i selve hjertet af den psykoanalytiske proces. « Fælles er også, at de hermed har givet litteraternes Freudlæsning en ny retning og en ny begrundelse. De har argumenteret for, at Freuds case-stories og hans overvejelser omkring det analytiske arbejde altid-allerede befinder sig indenfor litteraturteoriens og litteraturanalysens interessefære, og at det således ikke så meget drejer sig om at overføre indsigter fra ét vidensfelt (psykologien) til et andet (litteraturen), som om at fastholde, med Peter Brooks ord, at "den forklarings-struktur, der anvendes i en non-fiktiv genre, nemlig casestory'en, nødvendigvis indebærer spørgsmålet om fiktion/fiktionalitet «. ${ }^{9}$

Freud var selv den forste til at erkende, at psykoanalysen ikke kan komme uden om fortællingen som forklaringsmodel. Han har ikke blot bemærket, at 'det er mærkeligt som mine case-stories i den grad kommer til at ligne romaner; de synes så at sige at mangle videnskablighedens stempel'. Han har også, i forbindelse med en af sine tidlige case-stories (Dora-analysen) beskrevet forholdet mellem neurose og kur i narratologiske termer. I begyndelsen af Dora-analysen siger 
Freud săledes, at han diagnosticerer den hysteriske patient ved at lade vedkommende fortælle sin livshistorie. Hvis denne beretning tager form af en sammenhængende fortælling, så er patienten ikke hysteriker, men har måske bare et dårligt ben. Hvis beretningen derimod er lakunær og usammenhængende, så er der tale om psykisk lidelse. Forskellen mellem neurose og psykisk sundhed er altså forskellen mellem den mangelfulde og den velorganiserede fortælling. Eller sagt på en anden måde: neurotikeren er ude af stand til at fortælle sig selv som kohærent fortælling; den analytiske terapis målsætning er at tilvejebringe en sådan. »Det er forst henimod slutningen af behandlingen at vi har for os en konsistent, forståelig og ubrudt historie«, skriver Freud. ${ }^{10}$ Den analytiske proces er altså så at sige udspændt mellem to fortællinger: patientens uhensigtsmæssige fortælling og en anden, mere hensigtsmæssig, d.v.s. helbredende fortælling, som det er analysens mål at etablere.

Freuds bemærkninger er interessante, ikke blot fordi de så direkte fremstiller den psykoanalytiske terapi som en narrativ proces, men også fordi det er så store krav, der stilles - krav som case-story'en selv langt fra indfrier. Dora-analysen når aldrig frem til det punkt, hvor alle brikkerne falder på plads i et kohærent og ubrudt mønster. Den bærer forst og fremmest præg af patientens modvilje mod det 'plot', som Freud udkaster, og mod at indtage den plads, som han har tiltænkt hende. Analysen er Freuds fortælling; den bliver aldrig Doras egen. Sideløbende med, eller snarere sammenviklet med, den historic Freud søger at berette, aner vi sporene af en anderledes fortælling: den Dora vælger. I det hele taget er det karakteristisk, at analysen synes at producere heterogenitet; jo mere der analyseres, jo længere fjerner fortællingen om Dora sig fra idealet om en 'forståelig, konsistent og ubrudt historie'. Som Brooks skriver, udvikler analysen sig til en $\gg$ slags mislykket Edwardiansk roman, en af dem der aldrig kan nå til en tilfredsstillende løsning af gåden, og som aldig helt kan få hold på, hvordan forbindelserne mellem de forskellige personer egentlig er «. ${ }^{11}$

I følge Peter Brooks må vi læse Dora-analysen som en overgangstekst. Diskrepansen mellem ideal og praksis må ses i lyset af, at Freud er i færd med at opdage, at den psykoanalytiske fortælleproces er en hel del mere kompliceret, end han først troede, og at denne proces, som Brooks skriver, er uløselig forbundet med det fiktive. Som overgangstekst markerer Dora-analysen Freuds gryende erkendelse af, at den fortælling, han søger efter, ikke simpelthen ligger et eller andet sted og venter på at blive opdaget eller afdækket, men at den er et produkt af en fortolknings- og læseproces, der involverer ikke bare én 
men to læsere, analytikeren og hans patient. I Dora-analysen har Freud nemlig endnu ikke forstået, hvilken rolle overforingen spiller. Han har ikke forstået, at analysen udspilles i det kunstige rum, der skabes mellem analytiker og patient - det rum Peter Brooks kalder et "symbolsk « eller et »fiktivt og semiotisk sted «" ${ }^{12}$ og at dette semiotiske sted ikke bare er rammen om det, der skal fortælles, men nok så meget selve fortællingens indhold. Dora-analysen indvarsler i folge Brooks erkendelser, der kommer til udtryk i Freuds senere analyser. Nemlig: At den fortælling, som analysen tilvejebringer, er en fiktion, der fă sin realitet (og, kunne vi tilføje, sin terapeutiske effekt) idet den overføres. At den fortælling, der konstitueres i den analytiske proces, kun eksisterer som en del af en udvekslingsproces (mellem analytiker og patient). Og at forholdet mellem på den ene side den analytiske fortælling og, på den anden side, det fortidige begivenhedsforløb, som fortællingen skulle fremstille, derfor hverken er simpelt eller entydigt.

Brooks' kommentarer peger på, at det ikke er nok at bemærke, at psykoanalysen er en slags fortælle-teori; vi må tillige konstatere, at Freud bevæger sig fra én opfattelse af fortællingen til en anden langt mere kompliceret. Jeg er ikke helt enig med Brooks på dette punkt. For mig at se er det vanskeligt at lokalisere epistemologiske vendepunkter i Freuds forfatterskab. Snarere er der tale om at flere forskellige opfattelser af den psykoanalytiske proces eksisterer side om side. Freud formår indenfor rammerne af en enkelt, kort artikel at bevæge sig frem og tilbage mellem forskellige og tendentielt modstridende positioner. Artiklen »Konstruktion in der Analyse« er et eksempel på denne dobbelthed.

»Konstruktionen in der Analyse" stammer fra 1937 og er dermed et af Freuds sidste arbejder. Som titlen angiver, er artiklens emne den analytiske proces. »Konstruktion in der Analyse « handler om fortolkning og læsning i psykoanalysen, og den kredser om det spørgsmål, som Spence har stillet, nemlig; hvilken sandhedsværdi har den læsning (eller skulle vi måske hellere sige fortælling), som frembringes i den analytiske proces? Artiklen starter med en for så vidt ganske traditionel definition af analysens målsætning. Hensigten med analysen er at opløse fortrængninger, at bringe patienten til at erindre sin egen fortrængte forhistorie, og at tilvejebringe »et billede af patientens glemte år, der både er pålideligt og $\mathrm{i}$ alle henseender komplet «. ${ }^{13}$ Freuds artikel har altså som udgangspunkt den antagelse, at analysens mål er at afdække det, Spence ville kalde en historisk sandhed eller en historisk realitet. Men den ender et noget andet sted. I de sidste linier af artiklen introducerer Freud et begreb, som han kalder 
»historisk sandhed « - men det er vel og mærke et begreb, der er væsensforskelligt fra Spences, fordi det, Freud benævner »historisk sandhed «, kun kan forstås som hvad vi kunne kalde en realitets-effekt.

Argumentionen i »Konstruktionen in der Analyse« har karakter af en serie af til tider næsten umærkelige forskydninger eller glidninger. I et af sine første arbejder sagde Freud, at 'det neurotiske symptom forsvinder, når de traumatiske erindringer bringes for dagens lys. ${ }^{14}$ Denne opfattelse - som vi kan omskrive til udsagnet 'når sandheden kommer for dagens lys, forsvinder symptomet' - er Freuds udgangsposition i »Konstruktionen in der Analyse«. Via forskellige mellemled når Freud frem til en signifikant omformulering af denne position, en omformulering, som vi kan parafrasere på følgende måde: 'når symptomet forsvinder, så må vi være nået frem til en eller anden sandhed'. Igennem en glidning i argumentationen når Freud frem til et sandhedsbegreb, der kun hypotetisk kan udledes af en bestemt effekt. Men nu har jeg foregrebet begivenhedernes gang... Jeg vender igen tilbage til begyndelsen af »Konstruktionen in der Analyse " for skridt for skridt at gennemgå denne lille, men højest bemærkelsesværdige artikel.

Allerede fra starten går Freud i gang med at rokke ved vores forestillinger om, hvad den psykoanalytiske proces og den psykoanalytiske fortolkning går ud på. Analysen skal som sagt bringe patienten til at erindre den fortrængte fortid. Men denne proces forløber ikke af sig selv; den fordrer analytikerens aktive medvirken og indgriben. Den fortrængte fortid frembringes nemlig ikke som en erindring i den analytiske proces, fastslår Freud. Den fortrængte fortid frembringes faktisk slet ikke af patienten; tværtimod konstrueres den af analytikeren, på grundlag af patientens erindringsfragmenter. Freud skelner omhyggeligt mellem det, han kalder »tydning « (Deutung), og det han kalder konstruktion. Mens »tydning « betegner analytikerens dechiffrering af det materiale, patienten har frembragt, så betegner »konstruktion« det forhold, at analytikeren indtræder i patientens diskurs og tilfojer det, som patienten ikke kan sige, tilføjer det patienten ikke kan erindre. Konstruktionen udfylder hullerne i patientens beretning med et materiale, der tilhører analytikeren snarere end patienten. Når Freud skal give et eksempel på en analytisk konstruktion, så har dette eksempel karakterisk nok form af en lille fortælling. Hermed siger Freud en del om, hvad det er, der mangler i patientens beretning, og hvad det er, analytikeren må tilføje. Hvad der mangler, er det, der skal sætte patienten i stand til at fremstille sig selv $\mathbf{i}$ fortællingens form.

Konstruktionsbegrebet er selvsagt et kontroversielt begreb, og Fre- 
ud skynder sig at understrege sin 'videnskabelige ret' til at konstruere ved at sammenligne analytikerens konstruktion med arkæologens rekonstruktion af et gammelt tempel. Men denne analogi făr ikke lov at blive stående. Henimod slutningen opstiller Freud en ny, og langt mere overraskende, sammenligning. Den analytiske konstruktion kan sammenlignes med den neurotiske patients vrangforestilling, siger Freud. Både konstruktion og vrangforestilling er »forsøg på forklaring og helbredelse« (op.cit., p.405). De to analogier, analogien med arkæologien og analogien med vrangforestillingen, peger $\mathrm{i}$ hver sin retning. Analogien med arkæologien læser konstruktion som rekonstruktion; konstruktionen er et forsøg på at re-etablere en oprindelig historie. Analogien med vrangforestillingen fokuserer på konstruktionen som en fremadrettet fortolkningsaktivitet: et forsøg på at finde en mening og dermed et forsøg på at helbrede. Freuds to analogier indeholder derfor tendentielt to vidt forskellige svar på spørgsmålet om, hvad det vil sige, at en konstruktion er 'korrekt'. I henhold til arkæologi-analogien er konstruktionen rigtig, når den fremstiller fortiden, som den virkelig var. Analogien med vrangforestillingen peger på et andet 'sandhedskriterium': Konstruktionen er korrekt, når den 'virker', når den producerer en bestemt effekt.

Analogien mellem konstruktion og vrangforestilling har ført os ind på det emne, der hedder verificeringen af den analytiske konstruktion. Den analytiske proces er essentielt dialogisk. Når analytikeren har formuleret en konstruktion, præsenterer han den for patienten. Det er nu patientens opgave at verificere konstruktionen. Freud understreger, at denne verifikation selvsagt ikke kan tage form af en simpel bekræftelse eller en simpel afvisning. 'Selvsagt' siger jeg. For patientens verifikation er i sig selv paradoksal: patienten bliver bedt om at verificere noget, som han ikke har nogen erindring om. Kun den vej der hedder indirekte af- eller bekræftelse, er farbar: Enten lader konstruktionen patienten uberørt; han negligerer den. Sagt på en anden måde: konstruktionen har ingen effekt og er derfor forkert. Eller også begynder patienten selv at fortælle; han fortæller en historie, der er analog med analytikerens fortælling, eller træder ind $\mathrm{i}$ analytikerens konstruktion og bygger videre på det begivenhedsforløb, som han ikke kan huske. I så fald er konstruktionen korrekt, siger Freud - korrekt fordi den producerer en effekt. Den vellykkede analytiske proces er således to diskurser, der væves ind i hinanden og knyttes sammen på en måde, så at vi, i overføringens semiotiske og fiktive rum, ikke længere kan sige, hvem fortællingen tilhører. Denne fortælling, der altså har to fortællere og to modtagere, er en fortælling om patientens fortid, den fraværende fortid som hverken analytiker 
eller patient har privilegeret adgang til. Det er en fortælling om fortiden, der er produceret $\mathrm{i}$ analysen, og som kun kan verificeres i nuet, nemlig igennem den produktive - eller vi kunne sige narrative effekt, den har. Adskillige har kommenteret dette karakteristikum ved den psykoanalytiske proces. F.eks. Jürgen Habermas, der skriver: "Analytikeren giver fortolkningsforslag til en historie, som patienten ikke kan fortælle. Derfor kan disse forslag kun verificeres derigennem, at patienten tager dem til sig og ved hjælp af dem fortæller sin egen historie. Fortolkningen bekræftes alene igennem den vellykkede fortsættelse af en afbrudt skabelsesproces «. ${ }^{15} \mathrm{Og}$ Julia Kristeva: "Ligesom det deliristiske subjekt opbygger analytikeren, gennem fortolkning, en konstruktion, der kun er sand for så vidt som den udløser andre associationer hos patienten, og dermed udvider grænserne for det, der kan analyseres. Den psykoanalytiske fortolkning er m.a.o. kun i bedste fald delvist sand, og selvom den arbejder med fortiden, så er dens sandhed kun påviselig igennem dens effekter i det nuværende $\ll .{ }^{16}$

Sammenvævningen af analytikerens og patientens konstruktioner burde, i følge Freud, føre frem til det punkt, hvor fortrængningerne opløses, d.v.s. frem til det punkt, hvor konstruktionerne kan erstattes af 'autentisk' erindring. Den faktiske analyse viser imidlertid noget andet. Freud skriver:

\footnotetext{
"Ret så ofte lykkes det os ikke at få patienten til at erindre det fortrængte. I stedet frembringer vi, hvis analysen udføres korrekt, i patienten en sikker overbevisning om konstruktionens sandhed, der giver samme terapeutiske resultat som en genvunden erindring. Under hvilke omstændigheder dette sker, og om hvordan det er muligt, at det, der tager sig ud som en ufuldstændig erstatning, alligevel producerer et fuldstændigt resultat - alt det vil være emnet for en senere undersøgelse« (op.cit., p.403).
}

Som tidligere nævnt har Freud sagt, at symptomet forsvinder, når de fortrængte erindringer bringes for dagens lys, d.v.s. når erindringen om det begivenhedsforløb, der er årsag til symptomet, bringes frem. Men i den bemærkelsesværdige passage, jeg netop har citeret, adskiller han, ihvertfald momentant, symptomdannelsens årsag fra konstruktionens terapeutiske effekt. Resultatet er et andet sandhedsbegreb: den analytiske fortælling - den analytiske fiktion, kunne vi kalde den - er i stand til at helbrede, fastslår Freud. Erstatningen får samme effekt som en autentisk, genfunden erindring. Eller sagt på en anden măde: Den i analysen konstruerede fortælling kommer til at agere, som om den var autentisk erindring; den får realitets-effekt. Analysen når det punkt, hvor den fortælling, der er skabt af to fortællere i overføringens semiotiske og fiktive rum, 'overtages' af patien- 
ten; den analytiske fortælling får status og virkning som var den patientens egen erindring om sin fortid, sådan som den 'virkelig var'. "Konstruktionen former ikke blot fortiden - den bliver fortiden « skriver Spence (op.cit., p.175).

Jeg sagde indledningsvis, at man kunne bruge Spences begrebspar "historisk " og "narrativ" sandhed til at profilere nogle tendenser hos Freud. Men jeg har også sagt, at Spences begrebspar må revideres. Som tidligere angivet har Freud selv et begreb, der hedder »historisk sandhed « - et begreb der er forskelligt fra Spences. For Spence er historisk sandhed noget helt uproblematisk. Og også Freud har i parentes bemærket et begreb for denne uproblematiske, bogstavelige sandhed; han kalder den »materiel sandhed « eller »faktisk realitet.« Narrativ sandhed betegner hos Spence netop det fænomen, som den ovenfor citerede Freud-passage behandler, altså det forhold at den fortælling, der konstrueres i analysen, får en sådan overbevisende styrke, at den kan fungere, som om den var en historisk realitet. Det paradoksale er imidlertid, at det er på baggrund af præcis samme fænomen, at Freud fremsætter sin hypotese om en 'historisk sandhed'. Selv om de to begreber ikke er identiske, så er der, når det kommer til stykket, måske slet ikke så stor en forskel mellem det, Spence kalder »narrativ sandhed « og det, Freud »historisk sandhed «.

Spence bruger begrebet narrativ sandhed i forbindelse med analytiske konstruktioner, der, qua deres retoriske og fortolkningsmæssige styrke, făr en realitetsværdi. Freud bruger »historisk sandhed « der, som sagt, må holdes klart adskilt fra »materiel sandhed « i forbindelse med fiktive eller semi-fiktive konstruktioner og forestillingskomplekser, der har en vedholdende overbevisende kraft og en kraft til at forandre. Han bruger »historisk sandhed « i forbindelse med konstruktioner, der har realitetseffekt, også selv om de kun er erstatninger, og selv om de endda er i modstrid med den faktiske, materielle realitet. Hos Freud betegner »historisk sandhed " en referentiel hypotese. Antagelsen om en historisk sandhed er et forsøg på at forklare en effekt i det reale, som han faktisk ikke kan forklare. Når konstruktionen har sådan en overbevisende kraft, at den kan overbevise patienten om, at den er en faktisk del af hans livshistorie, og kan fungere $i$ overensstemmelse hermed, så må vi antage, siger Freud, at konstruktionen indeholder en kerne af historisk sandhed, en kerne der har magt til at overføre sin intensitet til de omkringliggende forestillinger. Historisk sandhed, skriver Peter Brooks, »adskiller sig ikke i sin status fra det, som Freud andetsteds kalder 'psykisk sandhed' d.v.s. det som er sandt for subjektet, hvad dets oprindelse end måtte være«. ${ }^{17}$ »Konstruktionen in der Analyse« er et tankevækkende bidrag til 
diskussionen af den psykoanalytiske proces og dermed til diskussionen af den fortælling, som denne proces sigter mod at etablere. Ved at forskyde interessen til den historie, der konstrueres i overføringens fiktive og semiotiske rum af en analytiker og en analysand, som indtager skiftende positioner i forhold til hinanden, gør den lille artikel op med en række vaneforestillinger om det analytiske arbejde. Den fortælling, der tilvejebringes i analysen, fremstår som en fortælling om fortiden snarere end en fortælling fra fortiden: den refererer til fortiden, men referenten kan kun hypotetisk udledes af en effekt i det aktuelle; den er en konstruktion, der kun kan gribes som erstatning, men som alligevel ikke er sekundær, idet den har samme virkning som det, den er en erstatning for.

I sine skrifter om litteratur og kunst har Freud ofte bemærket, at psykoanalysen må melde pas overfor værkets formale og æstetiske kvaliteter. En psykoanalytisk litteraturkritik, der henter sin begrundelse i Freuds egne forsøg på området, kan aldrig blive andet end en 'indholds-arkæologi'. Men forlader vi disse arbejder til fordel for f.eks. Freuds case stories og hans skrifter om det analytiske/terapeutiske arbejde, kan vi hævde, at psykoanalysen netop har et bud på en teori om fortællingen, en teori om fortællingen-som-form der samtidig rækker hinsides formalismen. Ved bestandig at kredse om emner som neurose og fortæller-kompetence, organiseringen af erindringer, den analytiske dialog, overføringen, analytiske konstruktioner, forholdet mellem (fraværende) fortid og fortiden som fortælling $\mathrm{i}$ analysen, case-story'ens form og problemet om den diskursive fremstilling af analytiske forløb, bliver psykoanalysen, som Peter Brooks har sagt, »en impliceret narratologi. « ${ }^{18}$ Fortællingen synes at være et felt, hvor psykoanalyse og litteraturforskning kan mødes på mere ligeværdige betingelser. På den ene side giver det god mening at anskue psykoanalysen fra fortællingens og narratologiens synsvinkel. På den anden side kan vi læse psykoanalysen som et sofistikeret bidrag til en teori om det narrative - en teori om fortællingen som struktur såvel som en teori om fortællingen som (psyko)dynamik og som handling. Freud har gjort os opmærksom på, at forholdet mellem fortællingen som specifik diskursiv fremstilling af begivenheder og det, der fortælles om, eller mellem fortællingen og dens referent er mere komplekst, end den traditionelle psykoanalytiske litteraturkritik troede. Og han har, som Spence skriver, gjort os opmærksom på den forførende og forandrende kraft, som den vel-konstruerede fortælling besidder - dens kraft til at helbrede, f.eks. 


\section{Noter}

1. Artiklen er en lettere revideret version af min licentiatforelæsning over emnet »En redegørelse for forholdet mellem biografisk-historisk sandhed og narrativ sandhed $\mathrm{i}$ relation til psykoanalytiske litteraturlæsninger.«

2. Peter Brooks, "The Idea of a Psychoanalytic Literary Criticism «, Critical Inquiry 13 (Winter 1987), p.334. Alle citater er oversat af mig, LM.

3. Shoshana Felman, "Turning the Screw of Interpretation«, Literature and Psychoanalysis (ed. Felman), Baltimore \& London 1982, p. 105.

4. Hayden White, "Historical Pluralism«, Critical Inquiry 12 (Spring 1986), p.484.

5. Donald P. Spence, Narrativ Truth and Historical Truth, New York \& London 1984, p. 21.

6. André Green, "The Analyst, Symbolization and Absence in the Analytic Setting ", International Journal of Psychoanalysis 56 (1975), p. 12.

7. Roy Schafer, "Narration in the Psychoanalytic Dialogue«, On Narrative (ed. Mitchell), Chicago \& London 1981, p. 26.

8. Paul Jay, Being in the Text, Ithaca \& London 1984, p.25.

9. Peter Brooks, Reading for the Plot, New York 1985, p.270.

10. Sigmund Freud, Bruchstück einer Hysterie-Analyse, GW V, p.175.

11. Peter Brooks, »Psychoanalytic Constructions and Narrative Meanings«, Paragraph (1986), p.54.

12. Peter Brooks, »Constructions psychoanalytiques et narratives«, Poetique 61 (Fevrier 1985), p.65.

13. Sigmund Freud, „Konstruktionen in der Analyse«, SA Ergz.Bd., p.396.

14. Nemlig i Studien über Hysterie (1893-95).

15. Jürgen Habermas, Erkenntnis und Interesse, Frankfurt am Main 1973, p.318.

16. Julia Kristeva, "Psychoanalysis and the Polis«, The Politics of Interpretation (ed. Mitchell), Chicago \& London, p.89.

17. »Constructions psychanalytiques et narratives«, p.71.

18. »Psychoanalytic Constructions and Narrative Meanings«, p.53. 